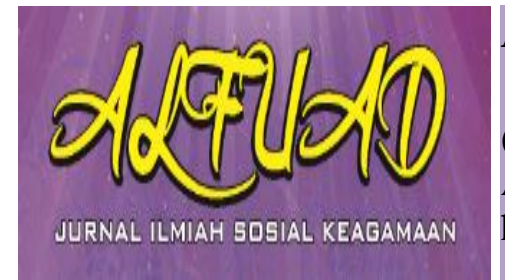

ALFUAD JOURNAL, 3 (2), 2019, (67-75)

(Print ISSN 2614-4786)

Available Online at

http://ecampus.iainbatusangkar.ac.id/ojs/index.php/alfuad

\title{
PERSPEKTIF ISLAM TERHADAP PENGEMBANGAN KOMPETENSI SUPERVISI MANAJERIAL DAN AKADEMIK PENGAWAS
}

\section{Jamilus}

Institut Agama Islam Negeri Batusangkar, Indonesia.

E-mail:tanjungjamilus@yahoo.com

\begin{abstract}
This discussion aims to describe the Islamic perspective on the development of supervisory managerial and academic supervisory competencies. This is important because the teachings of Islam have universal concepts and principles related to supervision or supervision and their competencies. Managerial supervision that emphasizes supervision and regulation of all elements in the education unit and academic supervision which is more in the form of assistance and guidance to teachers in improving the effectiveness of the process and learning outcomes, both require a number of competencies that must be developed continuously. Based on the Islamic perspective, then in its application managerial supervision competence must be based on the nature of Allah SWT al-Raqîb which means supervising and other traits in relation to being the regulator or manager of the universe with all its contents. While academic supervision competencies based on Islamic perspectives should prioritize the principle of helping to ease the burden and difficulties faced by others.
\end{abstract}

Keywords: Islamic Perspective, Academic Supervision, Supervisor

\section{PENDAHULUAN}

Guru dalam menjalankan tugas profesinya sebagai pendidik dan juga pengajar membutuhkan bantuan orang lain, baik untuk memecahkan masalah-masalah yang dihadapi maupun untuk meningkatkan kualitas keprofesiannya. Orang yang paling berperan membantu guru adalah Kepala Sekolah dan juga pengawas (supervisor) pendidikan, sedangkan upaya memberikan bantuan itu sendiri disebut dengan supervisi.
Secara etimologi, supervisi berasal dari bahasa Inggris, yaitu super dan vision. Super berarti di atas sedangkan vision berarti melihat.

Istilah supervisi masih satu rumpun dengan istilah-istilah lain seperti: inspeksi, penilikan, pengawasan, monitor dan penilaian (evaluasi), yang berarti kegiatan yang dilakukan oleh atasan (orang yang berposisi di atas), yaitu pemimpin terhadap orang-orang yang berada di bawah kepemimpinannya. Burhanuddin (2005: 99) menegaskan bahwa supervisi adalah 
kegiatan pengawasan yang dilakukan oleh seorang pejabat terhadap bawahannya dalam melakukan tugas dan kewajibannya dengan baik sesuai dengan tugas yang telah digariskan.

Inspeksi merupakan pengawasan yang dilakukan oleh pengawas (inspektur) mengenai pelaksanaan ketentuanketentuan, aturan-aturan atau undangundang yang telah ditetapkan. Pada umumnya pengawasan yang dilakukan oleh inspektur lebih banyak mencari kesalahan, dan kalau tidak sesuai dengan ketentuan akan dihukum.

Penilikan, selain mencari kesalahan dari orang yang diawasi, juga mencari hal yang baik untuk dikembangkan dan ditindaklanjuti. Pengawasan merupakan istilah yang hampir sama dengan supervisi, akan tetapi supervisi sifatnya lebih manusiawi (Arikunto, 2004). Monitor adalah kegiatan-kegiatan yang dilakukan petugas dalam usaha mengumpulkan data dan informasi untuk dijadikan bahan penilaian. Terakhir evaluasi merupakan kegiatan membandingkan keadaan suatu objek dengan objek lain berdasarkan ketentuan yang ada. Maka pengertian supervisi lebih luas dari kegiatan tersebut di atas (Asnawir, 2005).

Secara terminologi, supervisi adalah kegiatan yang dilakukan oleh pengawas satuan pendidikan dalam rangka membantu Kepala Sekolah, guru dan tenaga kependidikan lainnya guna meningkatkan mutu dan efektivitas penyelenggaraan pendidikan dan pembelajaran (Direktorat Tenaga Kependidikan, 2009). Menurut Good Carter dalam bukunya Dictionary of Education (dalam Soetopo, 1982), supervisi adalah segala usaha dari petugaspetugas sekolah dalam memimpin guru dan petugas lainnya untuk memperbaiki pengajaran termasuk menstimulasi, menyeleksi pertumbuhan jabatan dan perkembangan guru-guru, merevisi tujuantujuan pendidikan, bahan-bahan pengajaran, metode mengajar dan evaluasi pengajaran. Supervisi adalah proses bimbingan dari pihak atasan kepada guruguru dan para personalia sekolah lainnya yang langsung menangani belajar siswa untuk memperbaiki situasi pembelajaran dan mencapai tujuan yang diinginkan. Supervisor bertugas membina terutama guru-guru dalam membimbing siswa-siswa belajar dan menyiapkan fasilitas belajar mereka.

Supervisi merupakan bagian tak terpisahkan dalam upaya peningkatan prestasi belajar dan mutu sekolah. Sahertian (2000) menegaskan bahwa pengawasan atau supervisi pendidikan 
merupakan usaha memberikan layanan kepada stakeholder pendidikan, terutama kepada guru-guru, baik secara individu maupun kelompok dalam usaha memperbaiki kualitas proses dan hasil pembelajaran. Supervisi merupakan pengawasan utama atau pengontrolan tertinggi dalam satu lembaga (Departemen Pendidikan Nasional, 2005).

Supervisi dapat dibagi menjadi supervisi manajerial dan supervisi akademik. Hal ini berdasarkan Surat Keputusan Menteri Penertiban Aparatur Negara Republik Indonesia Nomor 118 tahun 1996 tentang Jabatan Fungsional Pengawas dan Angka Kreditnya, Keputusan bersama Menteri Pendidikan dan Kebudayaan Republik Indonesia Nomor 03420/O/1996 dan Kepala Badan Administrasi Kepegawaian Negara Republik Indonesia Nomor 38 Tahun 1996 tentang Petunjuk Pelaksanaan Jabatan Fungsional Pengawas dan Keputusan Menteri Pendidikan dan Kebudayaan Republik Indonesia Nomor 020/U/1998 tentang Petunjuk Teknis Pelaksanaan Jabatan fungsional Pengawas Sekolah dan Angka Kreditnya, bahwa fungsi pengawas sekolah meliputi: (1) Pengawasan penyelenggaraan pendidikan di sekolah sesuai dengan penugasannya pada TK, SD, SLB, SLTP dan SLTA dan (2)
Peningkatkan kualitas proses pembelajaran/bimbingan dan hasil prestasi belajar/ bimbingan siswa dalam rangka mencapai tujuan pendidikan. Fungsi yang pertama merujuk pada supervisi manajerial, sedangkan fungsi yang kedua merujuk pada supervisi akademik.

Untuk dapat melaksanakan kedua jenis supervisi tersebut secara efektif, baik Kepala Sekolah maupun pengawas dituntut memiliki kompetensi yang memadai. Kompetensi tersebut yaitu sebagaimana tertuang dalam Peraturan Menteri Pendidikan Nasional Nomor 12 Tahun 2007 tentang Standar Pengawas Sekolah/Madrasah yang meliputi 6 (enam) kompetensi, yaitu: kompetensi kepribadian, kompetensi supervisi manajerial, kompetensi supervisi akademik, kompetensi evaluasi pendidikan, kompetensi penelitian dan pengembangan serta kompetensi sosial. Lebih lanjut dari 6 kompetensi, pembahasan lebih dikerucutkan lagi pada kompetensi supervisi manajerial dan kompetensi supervisi akademik.

Sehubungan dengan profesi kepengawasan ini, Islam juga mengajarkan prinsip-prinsip penting dalam melaksanakan supervisi, baik supervisi manajerial maupun akademik. Lebih lanjut tulisan ini membahas bagaimana perspektif 
Islam terhadap pengembangan kedua kompetensi pengawas tersebut.

\section{METODE}

Melihat makna yang tersirat pada judul dan permasalahan yang dikaji, penelitian ini termasuk jenis penelitian pustaka (library research) yang menggunakan pendekatan kualitatif, yaitu penelitian yang tidak mengadakan penghitungan data secara kuantitatif (Moleong, 2003: 2). Ada beberapa kunci utama dalam penelitian literatur (pustaka) dengan pendekatan kualitatif, yaitu: (a) The researcher is the main instruments that will read the literature accurately; (b) The research is done descriptively. It means describing in the form of words and picture not in the form of number; (c) More emphasized on the process not on the result because the literature is a work that rich of interpretation; (d) The analysis is inductive; (e) The meaning is the main point.

Literatur utama atau primer yang menjadi rujukan dalam tulisan ini adalah buku-buku yang terkait dengan manjemen dan juga supervisi pendidikan seperti: Manajemen Pendidikan Indonesia karya Made Pidarta, Manajemen Pendidikan karya Asnawir, Supervisi Pendidikan karya Asnawir, Administrasi Pendidikan karya Asnawir. Literatur-literatur tersebut disadur supaya menjadi karya yang cukup baik dengan pemahaman yang sarat makna.

Metode pengumpulan data yang digunakan dalam tulisan ini adalah metode dokumentasi, yaitu data tentang variabel yang berupa buku, catatan, transkrip, surat kabar, majalah, jurnal, dan lain sebagainya. Sedangkan teknik analisis data yang dipilih adalah deskriptif analisis dengan menggunakan serangkaian tata fikir logis yang dapat dipakai untuk mengonstruksikan sejumlah konsep menjadi proposisi, hipotesis, postulat, aksioma, asumsi, ataupun untuk mengkonstruksi menjadi teori. Tata fikir tersebut adalah: (a) tata fikir perseptif, yang dipergunakan untuk memberikan persepsi data yang sesuai dan relevan dengan pokok-pokok permasalahan yang diteliti; (b) tata fikir deskriptif, yang digunakan untuk mendeskripsikan data secara sistematis sesuai dengan sistematik pembahasan yang dipakai dalam penelitian ini (Muhadjir, 1998: 55).

\section{HASIL DAN PEMBAHASAN}

\section{Kompetensi Supervisi Manajerial dalam Perspektif Islam}

Esensi dari supervisi manajerial dalam konteks pendidikan adalah kegiatan pemantauan, pembinaan dan pengawasan yang dilakukan oleh pihak berwenang atau 
supervisor (dalam hal ini pengawas pendidikan dan juga Kepala Sekolah) terhadap seluruh sumber daya yang ada pada satuan pendidikan binaannya dalam mengelola, mengadministrasikan dan melaksanakan seluruh aktivitas sekolah, sehingga dapat berjalan dengan efektif dan efisien dalam rangka mencapai tujuan pendidikan. Hal ini sejalan dengan pendapat Ramayulis (2012) yang menjelaskan bahwa supervisi atau pengawasan merupakan keseluruhan upaya pengamatan pelaksanaan kegiatan operasional guna menjamin bahwa kegiatan tersebut dapat terlaksana sesuai dengan rencana yang telah ditetapkan sebelumnya.

Pengawasan manajerial dalam perspektif Islam juga telah banyak diisyaratkan, baik di dalam al-Quran maupun hadis-hadis Nabi SAW. Hal ini karena sesungguhnya Allah SWT adalah manajer yang mengatur seluruh isi alam semesta ini sehingga berjalan dengan tertib dan teratur. Tanpa keteraturan tersebut, maka tidak mustahil alam akan menjadi hancur sehingga satu sama lain tidak lagi beredar pada orbitnya masing-masing dan bahkan saling bertabrakan.

Konsep mengenai pengaturan alam semesta dalam al-Quran dapat dikenal dengan beberapa istilah, di antaranya adalah melalui kata al-tadbîr. Kata ini merupakan derivasi dari kata dabbara yang artinya mengatur dan banyak ditemukan dalam al-Quran, seperti dalam firman Allah SWT surat al-Sajadah ayat 5 yang artinya: "Dia mengatur urusan dari langit ke bumi, kemudian (urusan) itu naik kepada-Nya dalam satu hari yang kadarnya adalah seribu tahun menurut perhitunganmu”. Ayat tersebut menjelaskan bahwa Allah SWT adalah pengatur alam (manajer). Keteraturan alam ini merupakan bukti kebesaran Allah SWT dalam mengelola alam semesta. Akan tetapi dalam konteks ini, Allah juga telah menciptakan manusia sebagai khalifah (pemimpin) di bumi. Maka manusia diberikan tanggung jawab untuk mengatur dan mengelola bumi dengan sebaikbaiknya sebagaimana Allah mengatur alam raya beserta isinya (Mutohar, 2016).

Untuk dapat melaksanakan tanggung jawabnya dengan baik, manusia juga telah dibekali oleh Allah SWT dengan beragam kompetensi. Salah satu kompetensi yang dimaksud adalah kemampuan untuk memberi arahan dan petunjuk antara satu dengan lainnya sesuai dengan yang diperintahkan oleh Allah SWT. Dalam al-Quran hal ini antara lain diisyaratkan dalam surat al-Sajadah ayat 24: "dan Kami jadikan di antara mereka 
itu pemimpin-pemimpin yang memberi petunjuk dengan perintah Kami ketika mereka sabar dan adalah mereka meyakini ayat-ayat Kami”.

Salah satu kegiatan penting dalam supervisi manajerial adalah melakukan pembinaan terhadap mereka yang telah diberikan tanggung jawab. Hal ini dimaksudkan untuk menciptakan perubahan ke arah yang lebih baik. Ajaran Islam juga senantiasa memberikan motivasi kepada umatnya dalam mewujudkan perubahan pola kehidupan dengan menekankan bahwa awal perubahan itu mesti dimulai dari itikad baik manusia itu sendiri. Sebagaimana firman Allah SWT dalam QS. Al-Ra'du ayat 11: "Sesungguhnya Allah tidak mengubah keadaan suatu kaum sebelum kaum itu sendiri mengubah apa yang ada pada diri mereka".

Sebagai manajer alam semesta, Allah SWT juga sekaligus berperan sebagai supervisor yang senantiasa mengawasi seluruh makhluk ciptaan-Nya. Oleh sebab itu, dikatakan bahwa Allah memiliki sifat Maha Mengawasi yaitu alRaqîb. Menurut Ibn Faris (1979) dalam kitabnya Mu'jam Maqayîs al-Lughah bahwa asal kata $a l-R a q i ̂ b$ ini menunjukkan makna yang satu, yaitu berdiri (tegak) untuk mengawasi atau memperhatikan sesuatu. Al-Fairuz Abadi menjelaskan bahwa kata al-Raqîb secara bahasa berarti pengawas, penunggu dan penjaga. Sementara Ibnu al-Atsir dan Ibnu al-Manzhur dalam kitabnya Lisân al-Arab menjelaskan bahwa nama Allah al-Raqîb berarti Maha Penjaga atau Maha Pengawas yang tidak ada sesuatupun yang luput dariNya.

Di antara ayat al-Quran yang memuat kata al-Raqîb terdapat dalam surat al-Nisa' ayat 1: 'Sesungguhnya Allah Maha Mengawasi kamu sekalian”. Menurut Ibnu Katsir dalam tafsirnya bahwa makna al-Raqîb pada ayat ini adalah zat yang Maha Mengawasi semua perbuatan dan keadaan manusia. Syekh Abdurrahman al-Sa'di berpendapat bahwa al-Raqîb adalah zat yang Maha Memperhatikan dan mengawasi semua hamba-Nya ketika mereka bergerak (beraktivitas), maupun ketika mereka diam, (mengetahui) apa yang mereka sembunyikan maupun yang mereka tampakkan, dan (mengawasi) semua keadaan mereka. Pada bagian lain al-Sa'di juga mengatakan bahwa al-Raqîb adalah zat yang Maha Mengawasi semua urusan (makhluk-Nya), Maha Mengetahui kesudahannya, dan Maha Mengatur semua urusan tersebut dengan aturan yang paling sempurna serta sebaik-baik ketentuan. 
Selanjutnya firman Allah dalam surat al-Ahdzab ayat 52: "Dan adalah Allah Maha Mengawasi segala sesuatu”. Begitu pula firman Allah dalam surat alMaidah ayat 117: "Dan akulah yang menjadi saksi terhadap mereka selama aku berada di antara mereka. Maka setelah engkau wafatkan (angkat) aku, Engkaulah yang Maha Mengawasi mereka. Dan Engkau adalah Maha Menyaksikan atas segala sesuatu”.

Dapat dipahami bahwa makna alRaqîb secara terperinci adalah zat yang Maha Memperhatikan atau Mengetahui apa yang tersembunyi dalam dada atau hati manusia, yang Maha Mengawasi apa yang diusahakan setiap diri manusia, yang Maha Memelihara semua makhluk dan menjalankan mereka dengan sebaik-baik aturan dan penataan yang paling sempurna, yang Maha Mengawasi semua yang terlihat dengan penglihatan-Nya, yang tidak ada sesuatupun yang luput dari-Nya, yang Maha Mengawasi semua yang terdengar dengan pendengaran-Nya, yang meliputi segala sesuatu, yang Maha Mengawasi atau Memperhatikan semua makhluk dengan ilmu-Nya yang meliputi segala sesuatu.

\section{Kompetensi Supervisi Akademik dalam Perspektif Islam}

Kompetensi supervisi akademik pada prinsipnya adalah kemampuan yang harus dimiliki oleh seorang supervisor dalam rangka membina guru-guru yang berada di bawah binaannya sehingga dapat meningkatkan kualitas pembelajaran dan hasil belajar peserta didik. Hal ini mengisyaratkan bahwa ruang lingkup kompetensi pengawas dalam melaksanakan supervisi akademik lebih spesifik dan lebih khusus dibandingkan ruang lingkup kompetensi pengawas dalam supervisi manajerial. Sebab sasaran dari supervisi akademik lebih terbatas pada pembinaan guru-guru dalam mengelola dan melaksanakan pembelajaran yang bermutu.

Pembinaan yang dilakukan oleh pengawas terhadap guru-guru pada satuan pendidikan yang berada di bawah binaannya pada prinsipnya merupakan wujud implementasi dari perintah saling tolong menolong yang telah digariskan dalam al-Quran. Tentu saja tolong menolong dalam hal ini selama berada dalam koridor kebaikan, bukan dalam hal bermaksiat terhadap Allah SWT. Dapat dimaklumi bahwa membantu para guru dalam memecahkan masalah yang dihadapi sehingga dapat meningkatkan mutu pendidikan adalah merupakan suatu 
Jamilus: Perspektif Islam Terhadap Pengembangan Kompetensi Supervisi Manajerial...

kebaikan. Hal ini sebagaimana diisyaratkan dalam firman Allah SWT surat al-Maidah ayat 2:

"Dan tolong menolonglah kamu dalam (mengerjakan) kebajikan dan takwa, dan jangan tolong menolong dalam berbuat dosa dan pelanggaran. Dan bertakwalah kamu kepada Allah, sesungguhnya Allah amat berat siksa-Nya".

Membantu para guru dalam memecahkan persoalan-persoalan yang dihadapi dalam pendidikan dan pembelajaran juga berarti bahwa pengawas setidaknya telah berpartisipasi meringankan beban para guru. Islam mengajarkan bahwa seseorang yang berupaya meringankan beban dan kesulitan orang lain, kelak setiap permasalahan dan kesulitan yang dihadapi juga akan diringankan oleh Allah SWT. Sebagaimana ditegaskan oleh Rasulullah SAW dalam sebuah hadis yang diriwayatkan dari Abu Hurairah r.a bahwa Nabi SAW bersabda:

"Barangsiapa yang melapangkan satu kesusahan dunia dari seorang mukmin, maka Allâh melapangkan darinya satu kesusahan di hari kiamat. Barangsiapa memudahkan (urusan) orang yang kesulitan (dalam masalah hutang), maka Allâh memudahkan baginya (dari kesulitan) di dunia dan akhirat. Barangsiapa menutupi (aib) seorang Muslim, maka Allâh akan menutup (aib)nya di dunia dan akhirat. Allâh senantiasa menolong seorang hamba selama hamba tersebut menolong saudaranya".

\section{KESIMPULAN}

Supervisi manajerial
supervisi yang menekankan pada
pengawasan dan pengaturan terhadap
seluruh elemen yang ada pada satuan
pendidikan. Sementara supervisi akademik
lebih bersifat pemberian bantuan dan
pembinaan terhadap guru dalam rangka
meningkatkan efektivitas proses
pembelajaran.

Baik supervisi manajerial maupun supervisi akademik memerlukan sejumlah kompetensi yang harus dikembangkan secara terus menerus dan berkesinambungan. Berdasarkan perspektif Islam, maka kompetensi supervisi manajerial yang menitikberatkan pada pengamatan aspek-aspek pengelolaan dan administrasi sekolah yang berfungsi sebagai pendukung (supporting) terlaksananya proses pembelajaran, mesti berlandaskan kepada sifat-sifat Allah SWT dalam kaitannya sebagai pengatur atau manajer alam semesta dengan segenap isinya. Sementarakompetensi supervisi akademik yang lebih menitikberatkan pada pengamatan supervisor terhadap kegiatan akademis, berupa pembelajaran, baik di dalam maupun di luar kelas, berdasarkan perspektif Islam seyogyanya lebih 
mengedepankan prinsip tolong menolong guna meringankan beban dan kesulitan yang dihadapi oleh orang lain.

\section{DAFTAR PUSTAKA}

Asnawir. (2005). Administrasi Pendidika., Padang: IAIN IB Press.

Arikunto, \& Suharsimi. (2004). DasarDasar Supervisi, Jakarta: Rineka Cipta.

Burhanuddin. (2005). Analisis Administrasi Manajemen dan Kepemimpinan Pendidikan. Jakarta: Bumi Aksara.

Direktorat Tenaga Kependidikan. (2009). Buku Panduan Pelaksanaan Tugas Pengawas Jakarta: Bumi Aksara.

Abadi, A. (1978). Qâmus al-Muhîth, Mesir, al-Hai'ah al-Mishriyyah al'Ammah li al-Kitab.

Fariz, I. (1979). Mu’jam Maqayîs alLughah, Beirut, Dar al-Fikr.

Komaruddin. (1974). Manajemen Organisasi. Bandung: Tarsito.

Moleong, L. J. (2003). Metode Penelitian Kualitatif. Bandung: Remaja Rosdakarya.

Muhadjir, N. (1998). Metode Penelitian Kualitatif. Yogyakarta: Rake Sarasin.

Mutohar, P. M. (2016). Manajemen Mutu Sekolah. Yogyakarta: Ar-Ruzz Media.

Nata, A. (2008). Manajemen Pendidikan (Mengatasi Kelemahan Pendidikan Islam di Indonesia). Jakarta: Kencana Prenada Media Group.

Peraturan Menteri Pendidikan Nasional No. 12 Tahun 2007 tentang Standar Kompetensi Pengawas Sekolah/ Madrasah.

Peraturan Menteri Pendidikan Nasional Nomor 19 Tahun 2007 Tentang Standar Pengelolaan Pendidikan oleh Satuan Pendidikan Dasar dan Menengah.
Peraturan Pemerintah Nomor 19 Tahun 2005 tentang Standar Nasional Pendidikan.

Ramayulis. (2012). Ilmu Pendidikan Islam. Jakarta: Kalam Mulia.

Rosyada, D. (2004). Paradigma Pendidikan Demokratis Sebuah Model Pelibatan Masyarakat dalam menyelenggarakan Pendidikan. Jakarta: Kencana.

Riva'i. (1992). Supervisi Akademik Kepala Sekolah. Bandung: Alfabeta.

Sahertian, P. A. (2000). Konsep Dasar dan Teknik Supervisi Pendidikan. Jakarta: Rineka Cipta.

Soetopo, H. (1982). Kepemimpinan dan Supervisi Pendidikan. Malang: Bina Aksara.

Surat Keputusan Menteri Penertiban Aparatur Negara Republik Indonesia Nomor 118 tahun 1996 tentang Jabatan Fungsional Pengawas dan Angka Kreditnya.

Thaib, M., Amin. B. R., dkk. (2005). Profesionalisme Pelaksanaan Pengawasan Pendidikan. Jakarta: Departemen Agama RI.

Wahjosumidjo. (2003). Kepemimpinan Kepala Sekolah. Jakarta: Raja Grafindo Persada. 